\title{
Geochemistry and ore potential of the Almoughlagh batholith, western Iran
}

\author{
Hassan Zamanian*, Behrooz Asadollahi \\ Dept. of Geology, Lorestan University, P.O. Box 465, Khoram Abad, Iran \\ *corresponding author; e-mail: hasanzamanian@yahoo.com
}

\begin{abstract}
The Almoughlagh batholith intruded the dioritic Baba Ali pluton during the Oligo-Miocene; the pluton and is now exposed as a big enclave within the batholith. The pluton intruded the Songhor Series during the Late Kimmeridgian ( $\sim 136 \mathrm{Ma})$ orogeny. The intrusion by the batholith transformed the diorite to metadiorite and the impure carbonate units of the Songhor Series. The batholith consists of rock types such as quartz syenite and syenogranite, which have a low average quartz content, and which are metaluminous to peraluminous and calc-alkaline in composition. Comparison of the compositions of the Almoughlagh batholith and the pluton with its $\mathrm{Cu}, \mathrm{Mo}, \mathrm{Fe}, \mathrm{Sn}, \mathrm{W}$, Au, and $\mathrm{Zn}$ skarn deposits, indicates that the Baba Ali diorite geochemically shows much resemblance with those which could bring about Fe-Cu skarn mineralization, whereas the compositions of the Almoughlagh granitoids resembles those of the plutons associated with Mo and Zn skarn deposits. The associated hydrothermal activity related to the Almoughlagh batholith culminated in magnetite mineralisation in the Baba Ali and the Chenar mines in which copper mineralisation also is considerable.
\end{abstract}

Key words: Fe-skarn mineralisation, Almoughlagh batholith, metaluminous, geochemistry, skarn ore potential, Baba Ali pluton

\section{Introduction}

The Almoughlagh batholith $(\mathrm{Ab})$ is located between $48^{\circ} 00^{\prime \prime}$ and $48^{\circ} 15^{\prime \prime} \mathrm{E}$ and between $34^{\circ} 50^{\prime \prime}$ and $35^{\circ} 00^{\prime \prime} \mathrm{N}$ in the Sanandaj-Sirjan Zone (S-S Zone) of Iran (Fig. 1). The Ab petrographically consists of three rock types, viz. quartz syenite, syenogranite and diorite, including some varieties (Tables 1 and 2). The evolution of the parent magmas played an important role that affected the composition of the post-magmatic fluids that resulted in different metal deposits. The geochemistry of the plutons can be a criterion to discriminate between the plutons, as well as to evaluate and predict the types of metal deposit accompanying the igneous bodies.
The present contribution deals with the various geochemical characteristics of the $\mathrm{Ab}$ to find out what metallic elements might be concentrated in the expected skarn deposit. Except for the South Ghorveh batholith (SGb), no mineralisation is known to be associated with these intrusives. The SGb, which is also situated in western Iran, intruded the volcanosedimentary Songhor Series (Triassic-Jurassic) during the Oligo-Miocene orogenic phase. SGb granitoids can roughly be classified as quartz monzonite to quartz monzodiorite, and as diorite. The granitoids of the SGb are low in free quartz, and show the characteristics of the I-type magnetite series, which is metaluminous and calc-alkaline. Adjacent to the SGb, a magnetite skarn deposit is present at Gelali. Petro- 


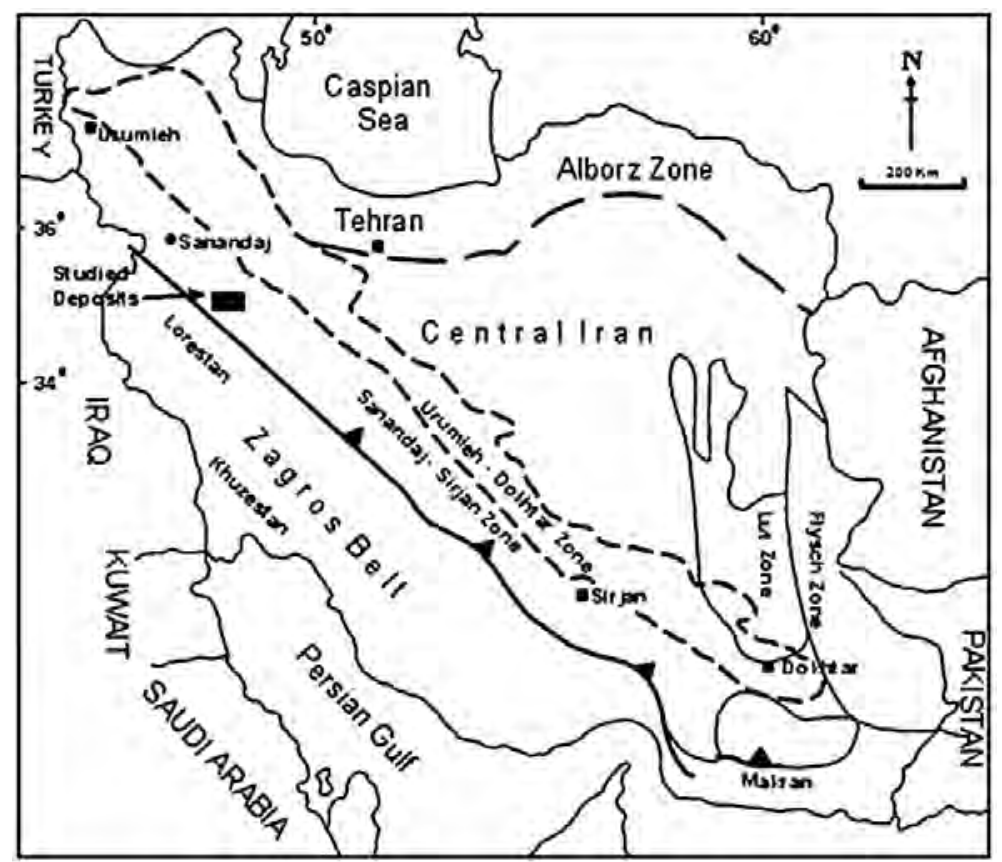

Fig. 1. Tectonic zones of Iran (modified after Berberian \& King, 1981; Nabavi, 1971). graphically the Gelali deposit has a simple ore mineralogy dominated by magnetite; martite, chalcopyrite and chalcocite are the main other ore-forming minerals. It can petrographically, geochemically, mineralogically be classified as an Fe-skarn - which is consistent with its classification in the field - and is characterised mainly by mixed calcic and magnesian skarn deposits (Zamanian, 2007).

\section{Geological setting}

The S-S Zone experienced multiple magmatic intrusions during the Jurassic (140 Ma); they are represented by the granodiorites of Golpaygan and Colah Ghazi, and by the diorite of Deh Bid; other intrusions followed during the Cretaceous-Palaeocene (65 Ma), represented by the Alvand, Burojerd, Arak, Aligodarz, Hassan Robat intrusions. Finally, intrusions took place during the Oligo-Miocene (37 Ma); these are represented by the south Ghorveh, Kamyaran, Kolasar, Pangwin and Golpaygan gabbro-diorites. Except for the South Ghorveh, no mineralisation accompanies these intrusives. The Almoughlagh batholith is $2 \mathrm{Ma}$ old (Amiri, 1995), indicating continuous magmatic activity in the S-S Zone even after the Miocene.
The rocks surrounding the Almoughlagh batholith have been subdivided into three main units, namely the Songhor Series (Triassic-Jurassic), the Hamadan Schists (Jurassic) and the Limy Formations (Oligo-Miocene) (Fig. 2). The Songhor Series is a volcanosedimentary succession, constituted of alternating schistose and limy units (Fig. 3) with interbedded metamorphosed spilitic volcanic rocks and andesitic tuff (Barud, 1975). The proportion of the volcanic rocks to the sedimentary rocks, regarding both layers and particles, is higher in the basal part of this unit; it decreases upwards.

The metavolcanic rocks are more frequent in the succession around Songhor, and become gradually less abundant towards the northearth, where the succession becomes less calcareous (Hamadan Schists) and eventually completely devoid of carbonates (Darvishzadeh, 1992). Towards Baba Ali and Chenar, on the other hand, the succession becomes gradually more calcareous, representing the younger part of the Songhor Series. The entire succession has been recognised as a flysch-type unit, and a Triassic-Jurassic age has been assigned to it by Barud (1975) on the basis of fossils such as corals, crinoids and foraminifers in the calcareous horizons that occur in the lowermost part of the Upper Songhor Series. 
Fig. 2. Geological setting. $\mathrm{Di}=$ diorite; $\mathrm{Om}=\mathrm{Oli}-$ go-Miocene; Jsh = Jurassic Hamedan schist; Gn = gneiss; $\mathrm{Am}=$ amphibolite; Son. Ser $=$ Songhor Series; Con $=$ conglomerate (from Zamanian, 2003).

A: Simplified geological map of the Baba Ali region. B: Geological map of the Almoughlagh batholith. C: Location map of the Baba Ali region.

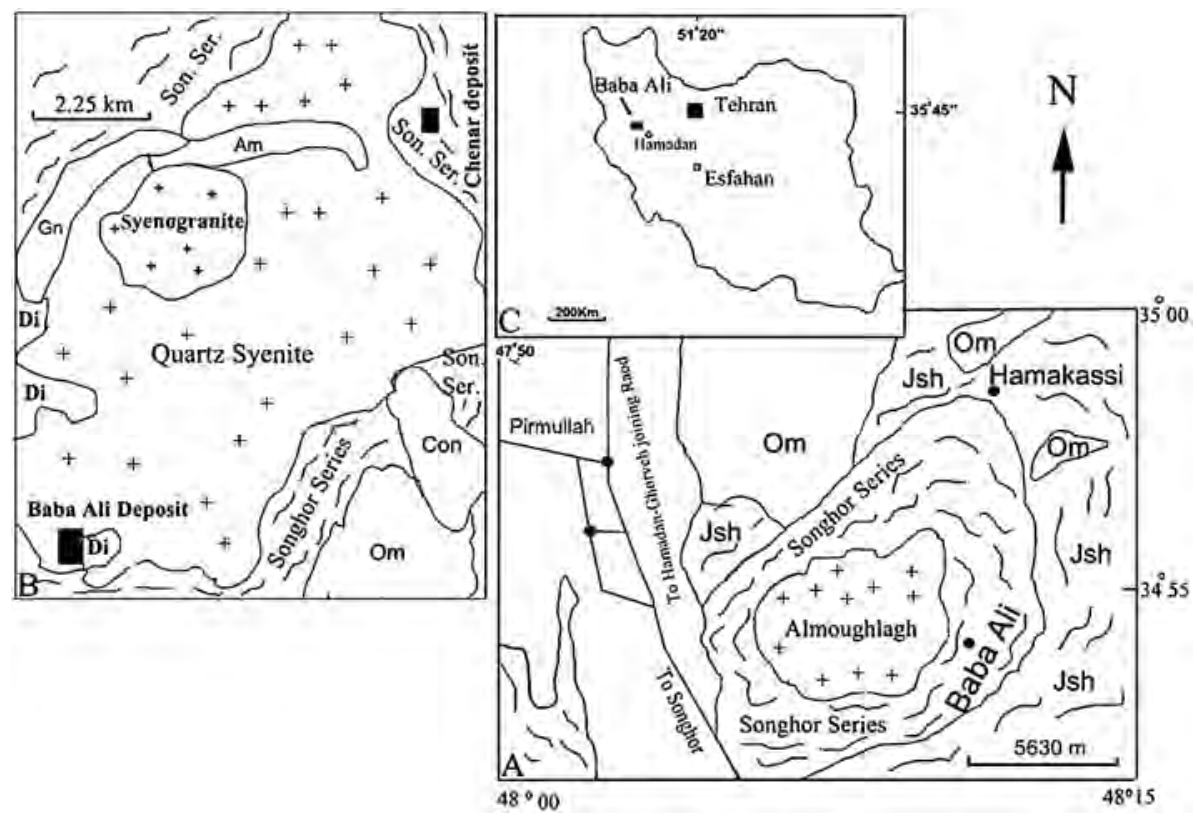

Small enclaves of Baba Ali metadiorite occur within and on the margins of the Almoughlagh batholith. They represent the non-assimilated and non-skarnised rocks which were subjected to regional metamorphism along with the Songhor Series. Petrographically, these rocks have a relict igneous texture; they are mediumto coarse-grained, consisting of phenocrysts of plagioclase (andesine to labradorite) within a groundmass of tiny plagioclase, quartz and hornblende. The phenocrysts contain evidence of deformation such as bending, microfaulting and homogenisation of polysynthetic twinning and have been sussuritised and calcitised. In

the Baba Ali magnetite skarn deposit, the main load of the magnetite ore body lies between the dioritic and quartz syenitic rocks of the batholith, hosted mainly by the metadioritic rocks. The metadioritic rocks show the effects of hydrothermal alteration, resulting in a distinct skarn zoning.

The deposition of this thick (>1000 m) flyschtype volcano-sedimentary succession probably started in the Early Triassic, coinciding with the beginning of an orogenic phase that forms part of the multistage tectonic activity in this region. The Baba Ali metadioritic rocks, which intruded the Songhor Series much earlier (144

SW

Fig. 3. Stratigraphy of the study area (from Zamanian, 2003).

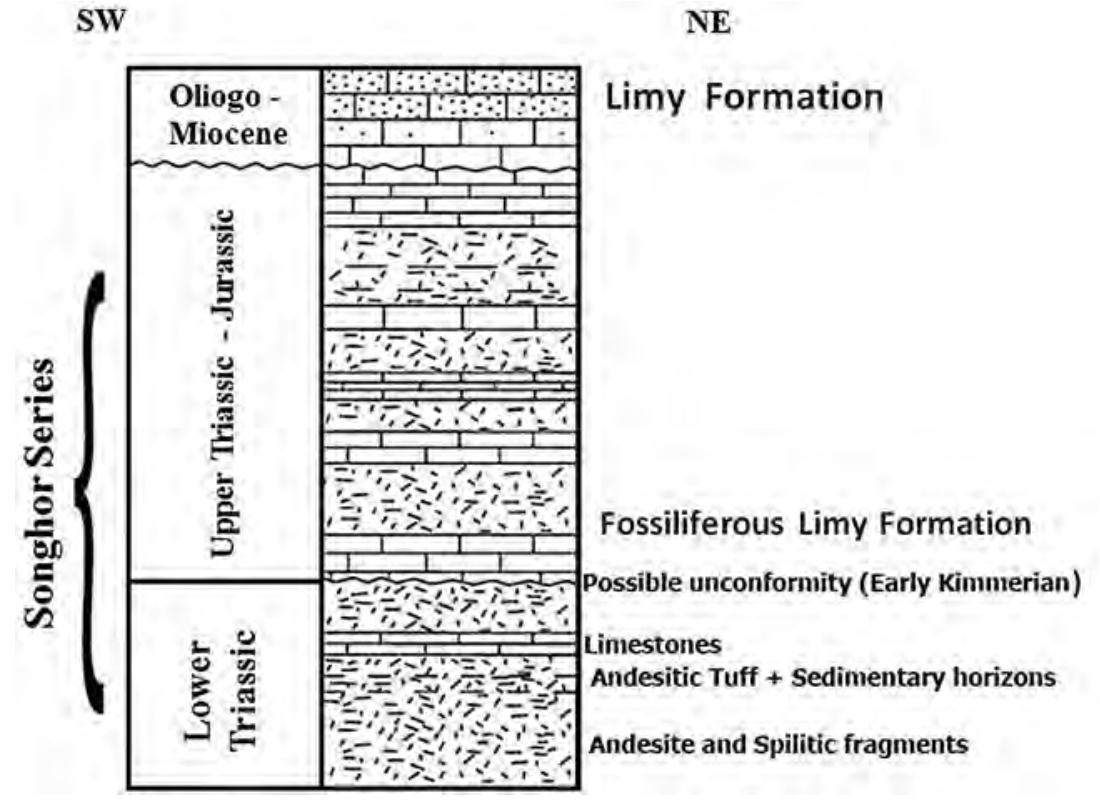




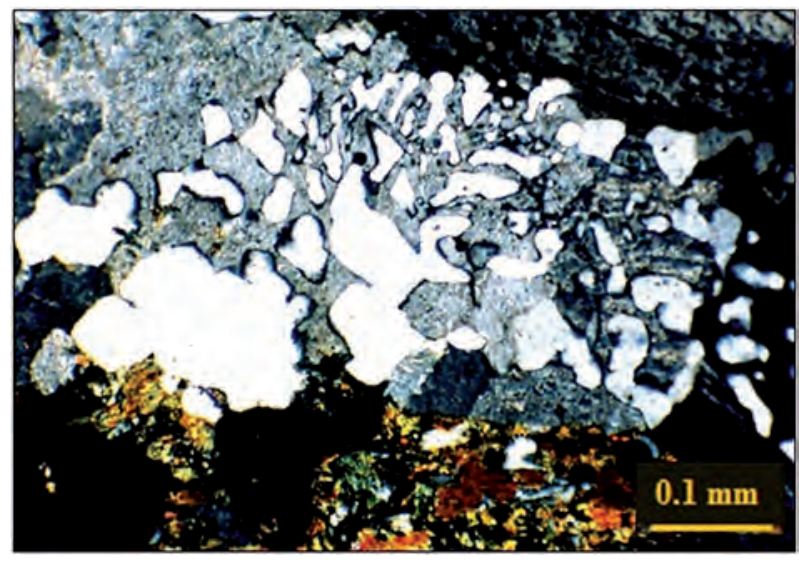

Fig. 4. Granophyric texture in alkali-syenogranite.

$\pm 17 \mathrm{Ma}$ ), were subject to regional metamorphism, related to the Late Kimmeridgian orogenic phase (Valizadeh \& Cantagral, 1975).

\section{Petrography}

The rock types of the Almoughlagh batholith have various compositions, viz. quartz syenite, gabbro and diorite (Valizadeh \& Cantagral, 1975). The present study found that the batholith petrographically is composed of two groups of mapable units, viz. groups including quartz syenite and syenogranite (Fig. 2B). The extent of the quartz-syenite group is much wider than that of the syeno-granite. Both groups are cut by relict enclaves of the metadioritic rocks (Zamanian, 2003).
The group of the quartz syenites consists of rocks that are porphyritic; they change to quartz alkalisyenite, alkali syenite and quartz monzonite (Table 1). Both the quartz syenite and the syenogranite show abundant K-feldspar phenocrysts that have mostly a perthitic form. The alkali-syenogranite and the monzogranite of the synogranite group and the quartz monzonite of the quartz syenite group contain neither amphibole nor biotite and show more commonly a granophyric texture (Fig. 4). The perthitic and granophyric textures thus provide evidence for the stage of crystallisation of feldspars when the volatiles escaped (Bose, 1991).

The QAP diagram (Fig. 5) does not show clustered compositions but rather a wide compositional spread, based on which the rock types have been identified. Granitoids have been classified on the basis of the presence of magnetite and ilmenite, as accessory minerals. The predominance of magnetite over ilmenite, the small amount of chalcopyrite, and the association of titanite, green biotite and epidote (pistacite) indicate that the Almoughlagh quartz syenites and syenogranites belong to the 'magnetite series' granitoids (Ishihara, 1981), and that they have emplaced under conditions of high oxygen fugacity (Liou, 1973; Shimaza$\mathrm{ki}, 1980)$. The Almoughlagh granitoids are devoid of accessory minerals like corundum, cordierite and sillimanite, but they contain significant amounts of primary titanite, magnetite

Table 1. Average chemical composition of the Almoughlagh batholith.

\begin{tabular}{|c|c|c|c|c|c|c|c|c|c|}
\hline \multirow[b]{2}{*}{$\begin{array}{l}\text { major } \\
\text { oxides }\end{array}$} & \multicolumn{5}{|c|}{ quartz-syenite group } & \multicolumn{4}{|c|}{ syenogranite group } \\
\hline & $\begin{array}{l}\text { quartz } \\
\text { syenite }\end{array}$ & $\begin{array}{c}\text { quartz } \\
\text { monzonite }\end{array}$ & $\begin{array}{c}\text { alkali } \\
\text { syenite }\end{array}$ & $\begin{array}{c}\text { quartz } \\
\text { alkali } \\
\text { syenite }\end{array}$ & mean & $\begin{array}{c}\text { alkali } \\
\text { syeno-granite }\end{array}$ & syeno-granite & $\begin{array}{l}\text { monzo- } \\
\text { granite }\end{array}$ & mean \\
\hline $\mathrm{SiO}_{2}$ & 70.84 & 64.28 & 71.33 & 77.96 & 71.1025 & 68.55 & 67.71 & 70.44 & 68.9 \\
\hline $\mathrm{Al}_{2} \mathrm{O}_{3}$ & 15.2 & 14.99 & 11.26 & 10.22 & 12.9175 & 14.12 & 14.52 & 14.5 & 14.38 \\
\hline $\mathrm{TiO}_{2}$ & 0.41 & 1.11 & 0.35 & 0.05 & 0.48 & 0.066 & 0.58 & 0.62 & 0.42 \\
\hline $\mathrm{F}_{2} \mathrm{O}_{3}$ & 2.08 & 3.24 & 0.02 & 0.03 & 1.34 & 3.5 & 2.03 & 2.13 & 2.55 \\
\hline $\mathrm{FeO}$ & 1.14 & 1.94 & 0.48 & 0.40 & 0.24 & 1.34 & 1.50 & 1.34 & 1.39 \\
\hline $\mathrm{MgO}$ & 0.58 & 1.02 & 0.12 & 0.17 & 0.47 & 0.26 & 0.32 & 0.34 & 0.92 \\
\hline $\mathrm{CaO}$ & 0.1 & 4.94 & 0.74 & 0.64 & 1.67 & 2.12 & 3.29 & 3.8 & 3.07 \\
\hline $\mathrm{Na}_{2} \mathrm{O}$ & 4.69 & 3.53 & 2.34 & 1.45 & 3.02 & 5.33 & 5.90 & 3.77 & 5.0 \\
\hline $\mathrm{K}_{2} \mathrm{O}$ & 3.74 & 4.01 & 9.94 & 7.90 & 6.39 & 5.22 & 4.41 & 3.53 & 4.38 \\
\hline $\mathrm{MnO}$ & 0.02 & 0.08 & 0.01 & 0.03 & 0.035 & 0.06 & 0.02 & 0.01 & 0.03 \\
\hline $\mathrm{P}_{2} \mathrm{O}_{5}$ & 0.13 & 0.30 & 0.22 & 0.01 & 0.16 & 0.15 & 0.16 & 0.13 & 0.14 \\
\hline
\end{tabular}


Fig. 5. QAP diagram showing the petrographic variations in 18 samples (1-18) from the Almoughlagh

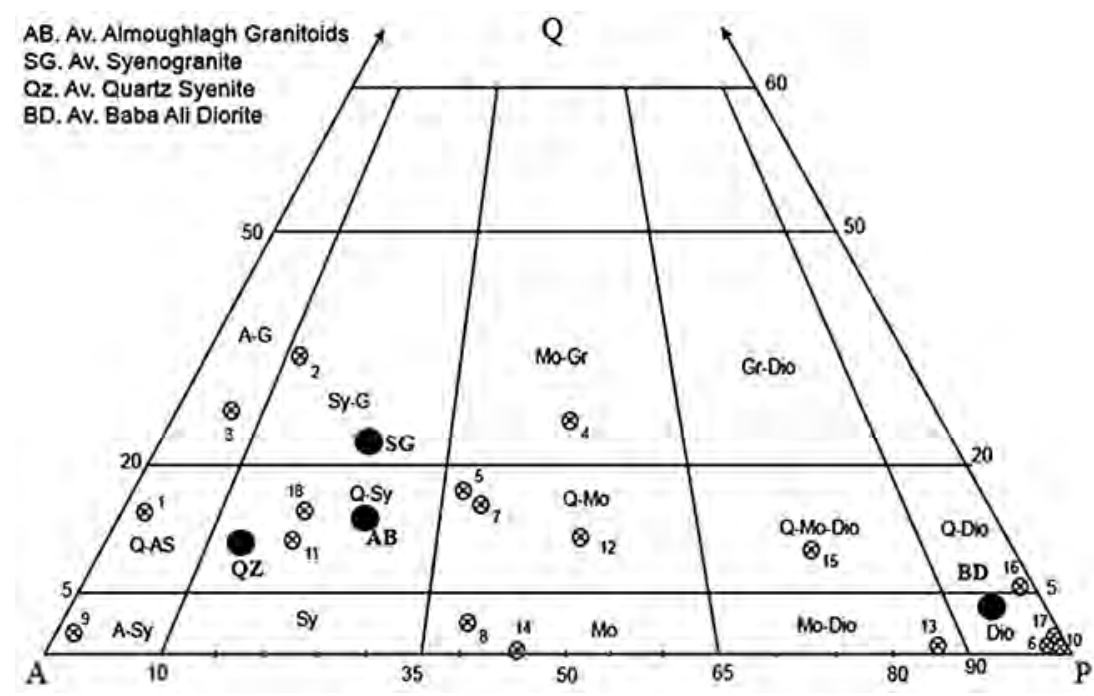
and Baba Ali diorites.

and hornblende, and are very poor in biotite and muscovite. Amongst the syenogranites, some rocks have a significant amount of muscovite without hornblende and biotite. Therefore, the quartz syenites belong petrographically to the I-type granitoids, whereas some other members of the syenogranite group belong to the S-type granitoids (Chappell \& White, 1984; Taylor \& McLennan, 1985).

In being poor to very poor in free quartz, while rich in K-feldspars, perthite and plagioclase, and having varying amounts of hornblende, while always containing magnetite and titanite, the Almoughlagh granitoids form a remarkable group. None of these rocks contain any feldspathoid, olivine or pyroxene and, thus - though rich in feldspars and perthite - they do not form the typical alkaline rocks (e.g. Ratnakar \& Kumar, 1995) that commonly occur associated with feldspathoid-containing rocks and carbonatites.

\section{Geochemical characteristics of the Almoughlagh batholith and the Baba Ali diorite}

Based on the petrographic classification, fresh representative rock samples from the Almoughlagh batholith have been geochemically analysed (Tables 1-2). The percentages of the major elements (as oxides), trace and some rare-earth elements were determined. Major
Fig. 6. Aluminium saturation (black dots) of the Almoughlagh granitoids and Baba Ali diorite. The ellipses indicate the mean composition of various plutons with related metals (of which the names are indicated). After Meinert (1984, 1995).

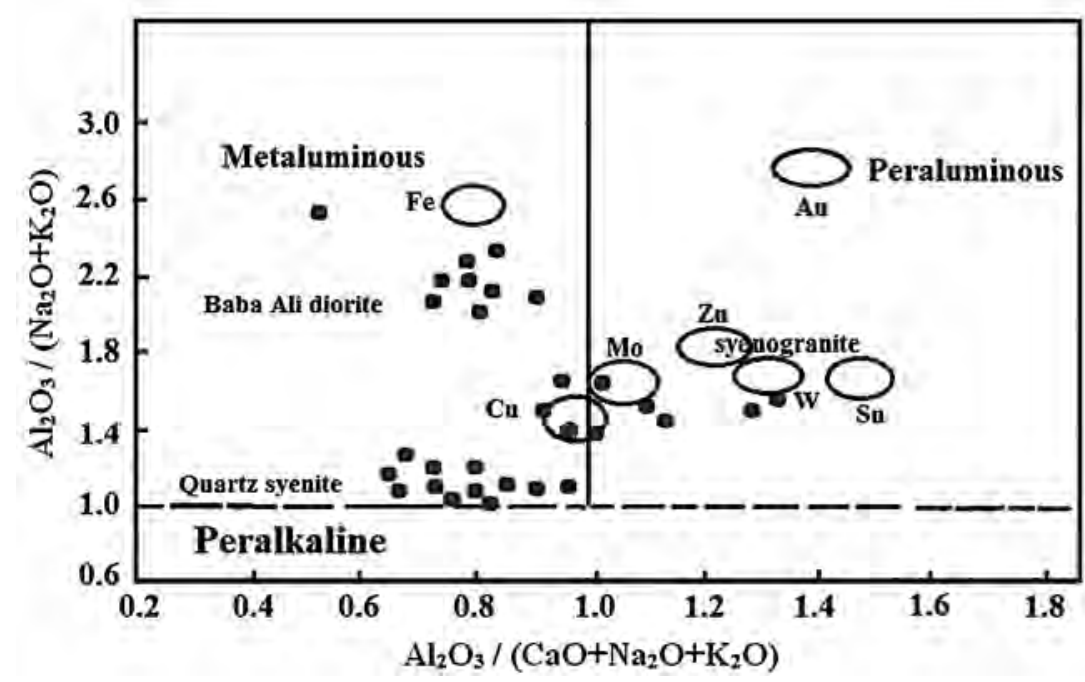



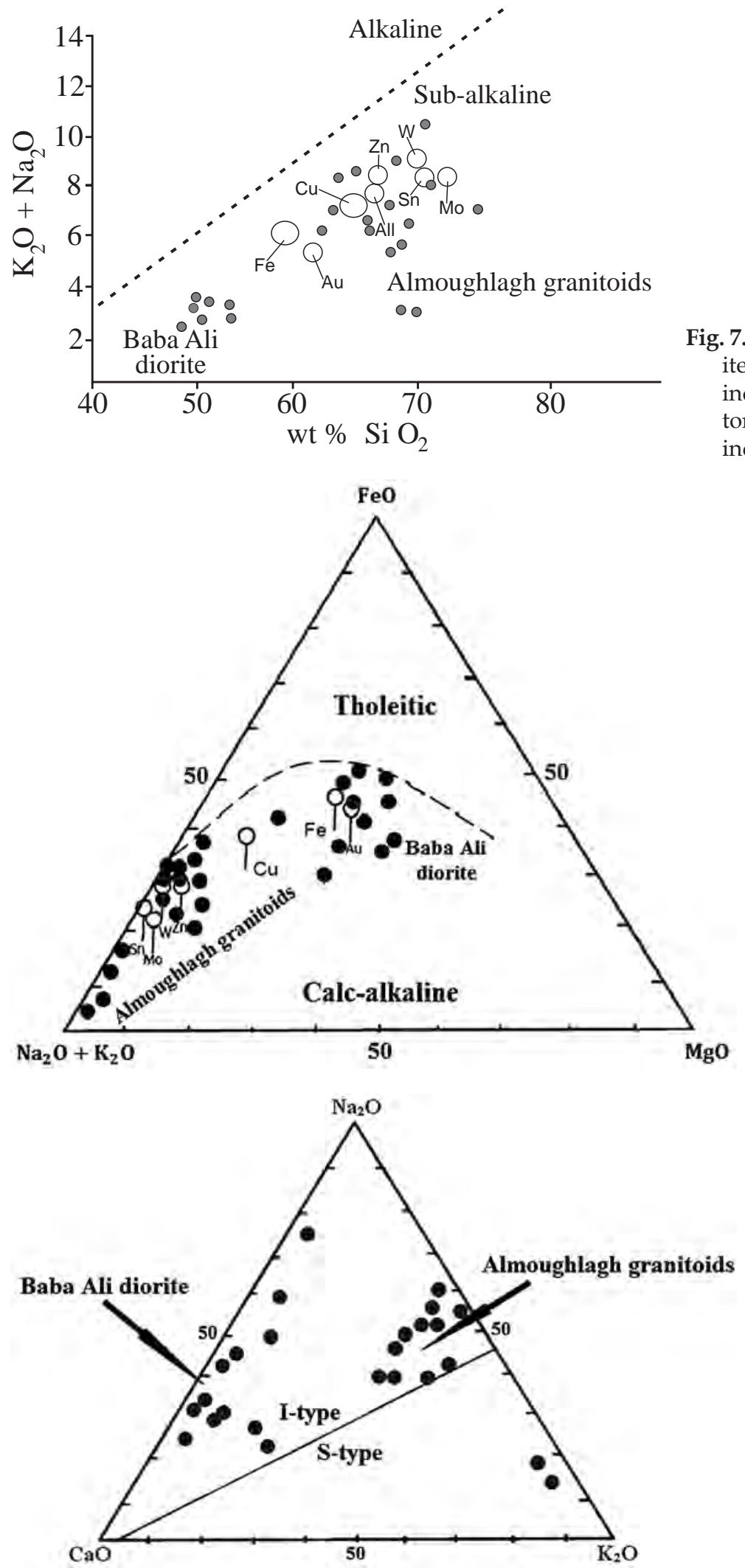

Fig. 7. Composition (black dots) of the Baba Ali diorite and the Almoughlagh granitoids The circles indicate the mean composition of various plutons with related metals (of which the names are indicated). After Meinert (1984, 1995).
Fig. 8. AFM diagram (after Irvine \& Baragar, 1971), showing the calk-alkaline nature of the Baba Ali diorite and the Almoughlagh granitoids (black dots) as well as the composition of the different skarn types (circles).

Fig. 9. $\mathrm{CaO}-\mathrm{Na}_{2} \mathrm{O}-\mathrm{K}_{2} \mathrm{O}$ diagram, discriminating I- and S-type granitoids (from Agrawal, 1999).

oxides were determined using an X-ray fluorescence spectrometer, whereas the trace and rare-earth elements were determined by In- ductively Coupled Plasma Atomic Emission Spectrometry (ICP-AES) at the Regional Sophisticated Instrumentation Center (RSIC) of 
Fig. 10. Variation of the $\mathrm{K}_{2} \mathrm{O}$ and $\mathrm{MgO}$ content vs. the $\mathrm{SiO}_{2}$ content for the Almoughlagh batholith (black dots). The circles indicate the mean composition of various plutons with related metals (of which the names are indicated). After Meinert, 1985.
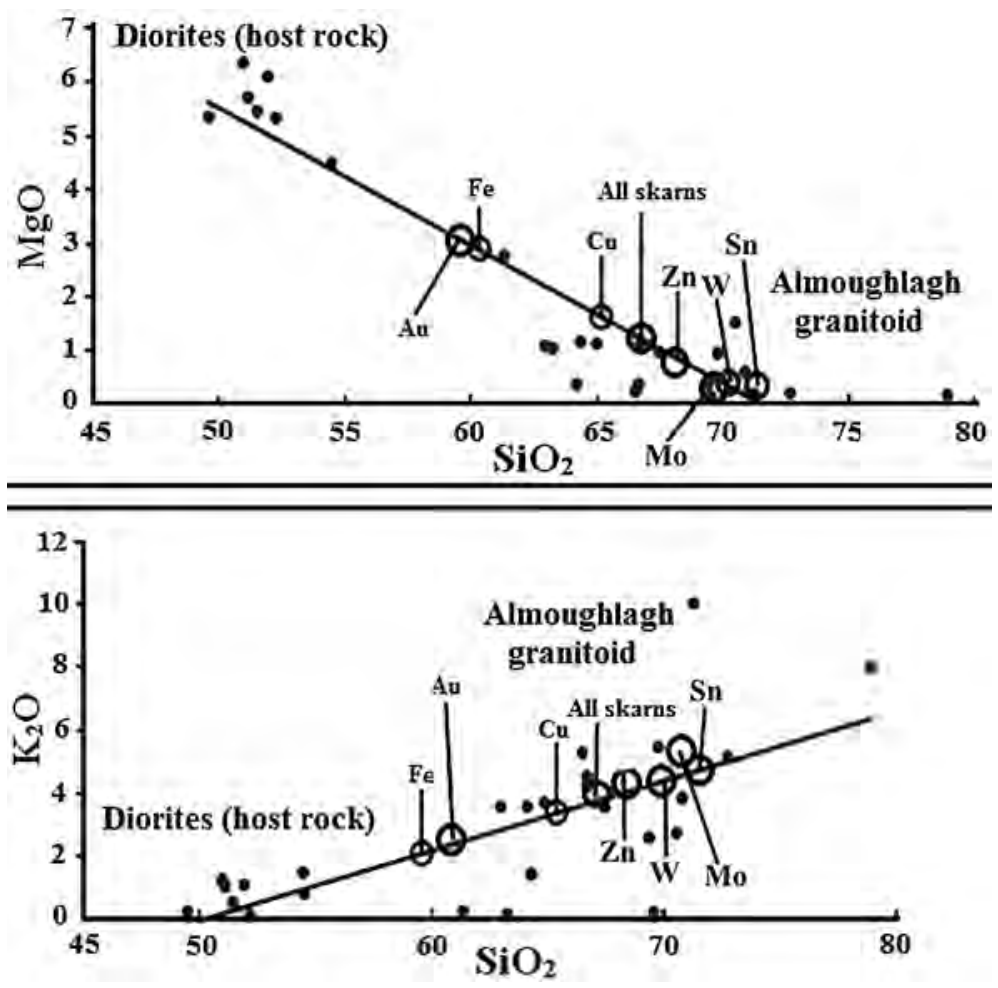

the Indian Institute of Technology, Mumbai, India.

Since the three constituents $\mathrm{CaO}, \mathrm{Na}_{2} \mathrm{O}$, and $\mathrm{K}_{2} \mathrm{O}$ controlled the crystallisation of the major minerals like plagioclase and alkali feldspars (including perthite), it was necessary to examine the alumina saturation of these two groups of felsic rocks by plotting the molar proportion of $\mathrm{A} / \mathrm{CNK}$ against that of $\mathrm{A} /(\mathrm{Na}+\mathrm{K})$ (Fig. 6). The syenogranite group has a higher $\mathrm{A} /(\mathrm{CNK})$ ratio than the alkali syenite group, while the Baba Ali diorite has a higher $\mathrm{Al}(\mathrm{Na}+\mathrm{K})$ ra-

tio than both the quartz syenite and the syenogranite. The quartz-syenite group is entirely metaluminous, while the compositions of the syenogranite group fall in both the metaluminous and the peraluminous fields, indicating a higher degree of fractionation.

In order to find out also the kind of magma from which these rock types originated, the compositions were plotted in alkali-silica and AFM diagrams (Irvine \& Baragar, 1971). Both the quartz-syenite and syenogranite groups of the Almoghlagh granitoids have a sub-alkaline com-

Table 2. Average chemical composition of the Baba Ali diorites.

\begin{tabular}{lccccc}
\hline \multicolumn{5}{c}{ Baba Ali diorites } \\
\multicolumn{1}{c}{ major oxides } & diorite & monzodiorite & $\begin{array}{c}\text { quartz monzodi- } \\
\text { orite }\end{array}$ & quartz diorite & mean \\
\hline $\mathrm{SiO}_{2}$ & 51.55 & 51.06 & 54.54 & 53.25 & 52.6 \\
$\mathrm{Al}_{2} \mathrm{O}_{3}$ & 17.51 & 18.04 & 17.31 & 15.40 & 17.05 \\
$\mathrm{Fe}_{2} \mathrm{O}_{3}$ & 3.27 & 3.92 & 3.75 & 6.51 & 4.36 \\
$\mathrm{FeO}$ & 4.02 & 4.58 & 3.92 & 5.59 & 4.52 \\
$\mathrm{MgO}$ & 5.3 & 6.33 & 4.47 & 5.30 & 5.35 \\
$\mathrm{CaO}$ & 10.6 & 8.5 & 7.2 & 3.82 & 7.53 \\
$\mathrm{Na}_{2} \mathrm{O}$ & 4.23 & 4 & 4.31 & 5.53 & 4.51 \\
$\mathrm{~K}_{2} \mathrm{O}$ & 0.4 & 1.25 & 0.8 & 0.35 & 0.7 \\
$\mathrm{TiO}_{2}$ & 1.34 & 0.79 & 1.08 & 1.71 & 1.23 \\
$\mathrm{MnO}$ & 0.015 & 0.18 & 0.15 & 0.09 & 0.1 \\
$\mathrm{P}_{2} \mathrm{O}_{5}$ & 0.31 & 0.26 & 0.34 & 0.41 & 0.33 \\
\hline
\end{tabular}


position (Fig. 7) and show a calc-alkaline trend of crystallisation (Fig. 8). Their compositions in the $\mathrm{CaO}-\mathrm{Na}_{2} \mathrm{O}-\mathrm{K}_{2} \mathrm{O}$ diagram (Fig. 9) are comparable with granitoids that are considered to have an igneous source (I-type). The dominance of magnetite over ilmenite, the low content of chalcopyrite and the association of titanite, green biotite and epidote (pistacite) among the accessory minerals indicate that the Almoughlagh syenogranite and quartz syenite also belong to the 'Magnetite series' granitoids (Ishihara, 1981) that are emplaced in high oxygen-fugacity conditions (Liou, 1973; Shimazaki, 1980).

The chemical composition of the metadiorites (Table 2), when compared with that of the Almoughlagh quartz-syenite and syenogranite groups, shows that the nature (Figs 6-9) of the two kinds of magma that intruded the same orogeny region is clearly different. Their compositional clusters fall close to the line of best fit, indicating similar compositional variations with increasing $\mathrm{SiO}_{2}$ (Fig. 10). Neither the Baba Ali diorite nor the Almoughlagh batholith rocks show any enrichment in iron with increasing silica content, a trend that is characteristic of fractionation of the calc-alkaline magmas (Miyashiro, 1974) that dominate island arcs and active continental margins.

Though not very different in their $\mathrm{Al}_{2} \mathrm{O}_{3}$ content, the two groups differ distinctly in the total $\mathrm{Na}_{2} \mathrm{O}+\mathrm{K}_{2} \mathrm{O}$ content (Fig. 7). The metadiorite is much richer in $\mathrm{CaO}(7-10 \%), \mathrm{MgO}(5-7 \%), \mathrm{FeO}$ (4-6\%) and $\mathrm{Fe}_{2} \mathrm{O}_{3}(2-7 \%)$ than the Almoughlagh felsic rocks. Compared to the average diorite (Perkins, 2002), the Baba Ali diorite is remarkably poor in $\mathrm{MgO}$ and $\mathrm{FeO}$, similar in $\mathrm{SiO}_{2}, \mathrm{CaO}$ and $\mathrm{K}_{2} \mathrm{O}$, but richer in $\mathrm{Na}_{2} \mathrm{O}, \mathrm{Al}_{2} \mathrm{O}_{3}$ and $\mathrm{Fe}_{2} \mathrm{O}_{3}$. These characteristics represent the possible effect of contamination and assimilation of Songhor Series elements as well as of the later interaction with the Almoughlagh magma.

\section{Baba Ali skarn}

Small enclaves of the Baba Ali metadiorite occur within and on the margins of the Almoughlagh batholith. In the Baba Ali magnetite skarn deposit, the main magnetite ore body lies between the dioritic and quartz-syenitic rocks of the batholith, hosted mainly by the metadioritic rocks. The latter show effects of hydrothermal alteration, resulting in eight distinct skarn zones (Fig. 11).

Zone 1 consists of the syenites of the $\mathrm{Ab}$. The intrusion and the emanations from these rocks thermally metamorphosed the metadiorite and caused skarnization. The modal composition of the rocks of this zone is presented in Table 3.

Zone 2 consists of altered quartz syenite. Moving NW from zone 1 towards the ore body, the syenite rocks show more and more hydrothermal alteration features, the original igneous features disappear gradually. The abundance of vein minerals like epidote, quartz, titanite, idocrase and magnetite distinguishes this zone from zone 1. Magnetite occurs as scattered grains within veins, associated chiefly with epidote and quartz.

From zone 2 to zone 3 , the amounts of epidote, vein calcite and magnetite increase rapidly and the primary igneous minerals like

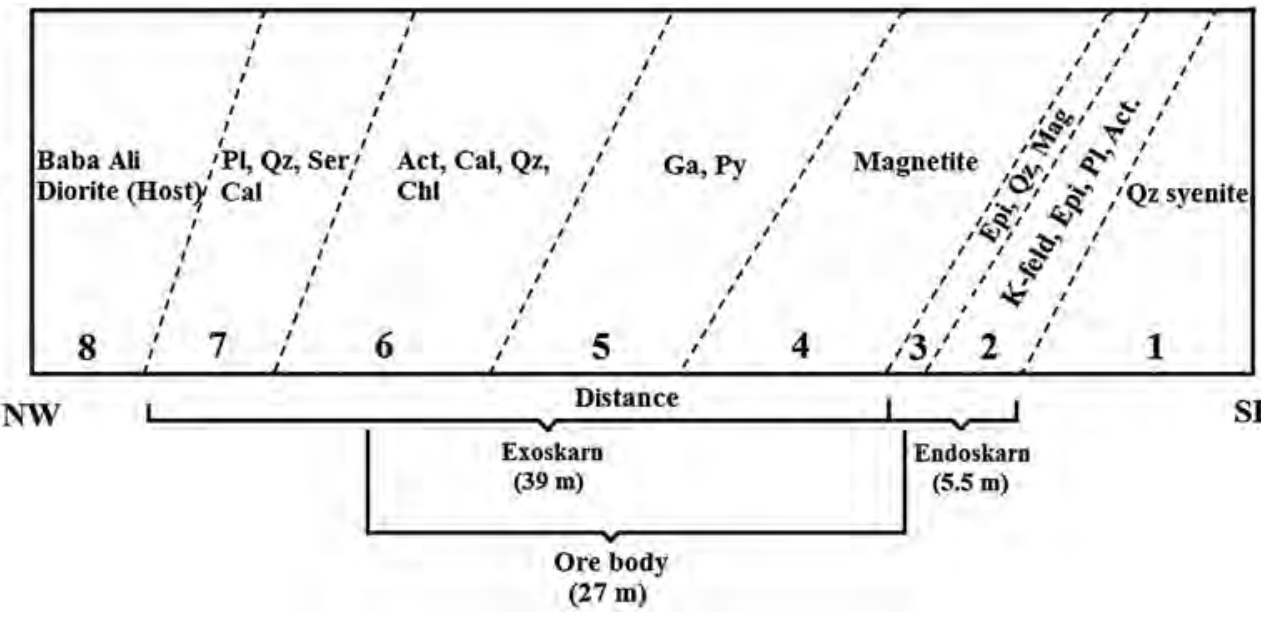

Fig. 11. The Baba Ali deposit with zones of the endo- and exoskarn. The most abundant minerals in each zone are indicated. 
Table 3. Average modal composition of the Almoughlagh granitoids (Zamanian, 2007).

\begin{tabular}{|c|c|c|c|c|c|c|c|}
\hline \multirow[b]{2}{*}{ mineral } & \multicolumn{4}{|c|}{ quartz syenite group } & \multicolumn{3}{|c|}{ syenogranite group } \\
\hline & $\begin{array}{l}\text { alkali- } \\
\text { syenite }\end{array}$ & quartz syenite & $\begin{array}{l}\text { quartz mon- } \\
\text { zonite }\end{array}$ & $\begin{array}{c}\text { quartz alkali } \\
\text { syenite }\end{array}$ & $\begin{array}{l}\text { monzogran- } \\
\text { ite }\end{array}$ & $\begin{array}{c}\text { alkali } \\
\text { syenogranite }\end{array}$ & syenogranite \\
\hline plagioclase & 3 & $9.5-14$ & $25-30$ & 2 & 30 & 4 & 7 \\
\hline K-feldspar & 89 & $39.5-51$ & $34.5-45$ & 67 & 29 & 54 & 52.5 \\
\hline quartz & 3 & $9-10$ & $10-15$ & 13 & 19 & 20 & 25 \\
\hline hornblende & - & $20-27$ & $2.5-25$ & 14.75 & - & - & 10 \\
\hline chlorite & - & - & $2.8-5$ & 2 & 6 & - & 1 \\
\hline calcite & - & - & $0.2-2$ & - & - & - & - \\
\hline biotite & - & - & $0-2.5$ & - & - & - & - \\
\hline tourmaline & - & - & - & - & 8 & - & - \\
\hline titanite & 2.5 & $2.5-5$ & $1.5-4$ & - & - & 3 & 3 \\
\hline muscovite & 0.5 & $0-0.5$ & $0-0.5$ & - & 8 & 16 & - \\
\hline epidote & 0.0 & $0-2.5$ & $0-2$ & - & - & - & 1.5 \\
\hline magnetite & 2.0 & $0-4$ & $0-1$ & 2 & 1.5 & 3 & 0.5 \\
\hline total & 100 & - & - & 100.75 & 101.5 & 100 & 100 \\
\hline
\end{tabular}

K-feldspar, plagioclase and hornblende totally disappear. This zone shows the highest concentration of vein epidote ( $65 \%$ by volume) and $t$ ( $8 \%$ by volume) of all skarn zones (Fig. 12a) of the Baba Ali rocks. The paragenetic sequence in the vein-mineral assemblage, as based on texture is calcite » quartz » titanite » (actinolite + epidote) $»$ magnetite. This zone is immediately adjacent to the ore zone in the NW and forms, more or less, the footwall of the ore body (Fig. 12b).

Zone four is the main mineralised zone. The ore (50-100\% magnetite) is associated with epidote, calcite, actinolite, tourmaline, apatite, and quartz. The texture shows magnetite as disseminated grains, as cross-cutting veins and as massive magnetite, replacing all other vein minerals (Fig. 12c, b). The paragenetic sequence is similar to that of zone 3, apart from that titanite is absent in this sequence.

Zone 5 is the most informative zone of the Baba Ali skarn deposit, since it provides the opportunity to establish the intensity of the thermal metamorphism before the rocks suffered hydrothermal veining and mineralisation. It is characterised by index minerals like garnet and pyroxene and preserves the skarn mineral assemblage beyond the zone of magnetite mineralisation.

Zone 6, situated towards the dioritic host rock, is characterised by the abundance of actinolite, quartz and calcite. The appearance of chlorite, the decreasing abundance of epidote and magnetite, and the rapid decrease of garnet and pyroxene are other characteristics of this zone.

The altered diorite zone (zone 7) is characterised by the gradual decrease of actinolite, calcite and epidote (compared to zone 6) and an increasing appearance of sericite, plagioclase, K-feldspar and quartz. This zone has the highest concentration of quartz $(42 \%$ by volume) and sericite ( $10 \%$ by volume), indicating effects of hydrothermal alteration induced by the Almoughlagh granitoids.

The zones 4, 5, 6 and 7 together constitute the exoskarn. This exoskarn in the Baba Ali deposit is much wider than the endoskarn: the exoskarn has a radius of $39 \mathrm{~m}$, whereas that of the endoskarn is $5.5 \mathrm{~m}$. The ore body, with its width of nearly $27 \mathrm{~m}$ is positioned mostly within the exoskarn, but some mineralisation is also associated with zones 2 and 3, within the endoskarn. The extensive exoskarn confirms that the role played by the dioritic host rock was comparable to that of any carbonate host rock that is usually known to form a geochemical barrier for the precipitation of the metal content of ore-bearing fluids. The peripheral metadiorite zone (zone 8) has the same characteristics as described earlier for the Baba Ali diorite (host rock). The occurrence of calcite as the only vein mineral and intersertal re-crystallized grains is significant. 

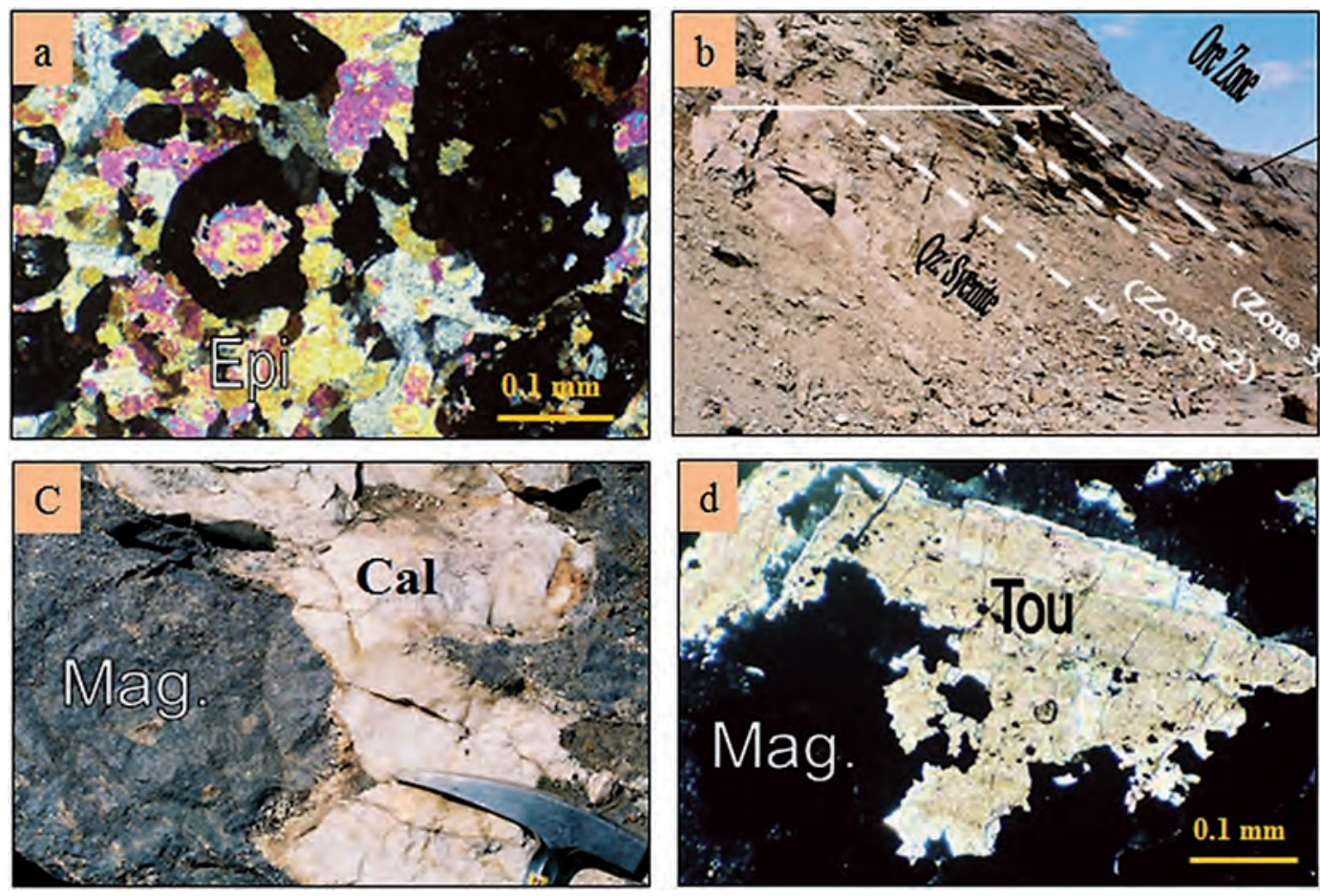

Fig. 12. Characteristic aspects of the zones of the Baba Ali deposit.

a: Epidote grains replaced by magnetite in zone 3 .

b: The epidote and quartz zones constituting the footwall of the ore body at the Baba Ali deposit.

c: Massive grains of magnetite replacing hydrothermal calcite in the Baba Ali ore zone.

$\mathrm{d}$ : Massive grains of magnetite replacing hydrothermal tourmaline in the Baba Ali ore zone.
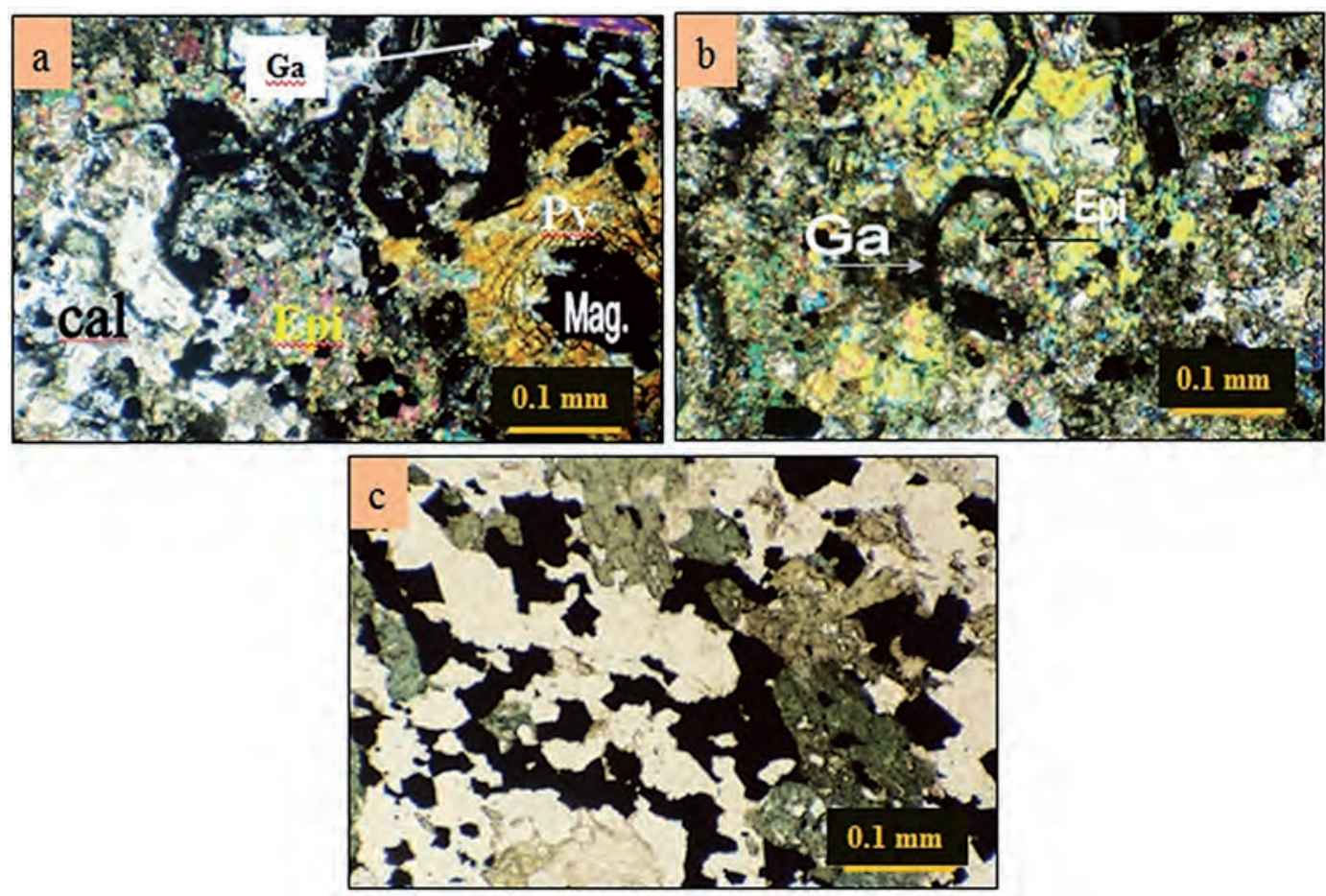

Fig. 13. Mineral characteristics.

a: Coexisting garnet and pyroxene in zone 5.

b: Epidote (pistacite) replacing both pyroxene and garnet, forming pseudomorphs of garnet grains.

c: Magnetite veins associated with calcite and epidote in zone 6. 


\section{Ore petrography}

The ore petrography of the samples from zone 4 reveals a simple ore mineralogy dominated by magnetite with minor contributions of pyrite, chalcopyrite and chalcopyrrhotite. The magnetite is whitish gray without any anisotropy or exsolution product, indicating a lack of any mixed-crystal development (Ramdohr, 1980). Magnetite occurs as idiomorphic, equigranular massive grains, as vein minerals filling open spaces and substituting pre-existing minerals like garnet, pyroxene, calcite, plagioclase, amphibole and epidote (Figs 12 and 13).

\section{Discussion of the skarn ore potential}

Some significant differences concerning both the major and the trace elements occur among plutons that lead to the formation of $\mathrm{Au}, \mathrm{Cu}, \mathrm{Zn}, \mathrm{W}, \mathrm{Mo}$ and Sn skarns (Meinert, 1995). Two general groups of plutons are recognised and their distinction is based largely upon the extent of their interaction with oceanic/continental crust. Plutons that lead to $\mathrm{Sn}, \mathrm{Mo}$ and $\mathrm{W}$ skarns show a much stronger continental-crust signature than do plutons that lead to $\mathrm{Fe}, \mathrm{Cu}, \mathrm{Au}$ and $\mathrm{Zn}$ skarns (Meinert, 1995). The evolution of magmas can culminate in different supplies of metals to the post-magmatic fluids, so that eventually different metal deposits are produced. Dissolved volatile components in the magma have a strong influence on the crystallisation of amphiboles and feldspars. In the presence of water, K-feldspar and plagioclase have a stronger tendency to form individual crystals (hypersolvous condition). With the gradual escape of volatiles, the feldspars tend to form a solid solution (subsolvous condition), and eventually to form, during cooling, perthite. In extreme cases, when the volatiles escape, very little time is left even for the K-feldspar and quartz to form individual crystals and they form intergrowths (granophyric texture) (Bose, 1991). Mo-W-Sn deposits are connected with felsic and fractionated granites (Blevin \& Chappell, 1995). Tungsten mineralisation correlates with granitic mag- mas of a transitional character and $\mathrm{Cu}-\mathrm{Au}$ deposits with more mafic granites. Granite-related $\mathrm{Cu}$ deposits are associated with less fractionated granites (Blevin \& Chappell, 1995). The plutons adjacent to Fe-Cu skarns lack the continental-crust signature. They are generally of the I-type, metaluminous, low in silica, ironrich and relatively primitive (Meinert, 1993).

However, Mo and $\mathrm{W}$ deposits are associated with more fractionated granites, and tin deposits are even associated with the most fractionated and reduced granites (Blevin \& Chappel, 1995; Baker et al., 2005). Granite-related Cu and Mo deposits are associated with I-type intrusions, whereas $\mathrm{W}$ and $\mathrm{Sn}$ deposits are associated with both S- and I-type granites (Baker et al., 2005). The oxidation state of the magma is of paramount importance in controlling the nature of many ore elements and allows for division of granites into ilmenite and magnetite series (Ishihara, 1981). There is a general trend to decrease the relative oxidation state in granite from an arc settings through a continental-margin setting to that of a continental interior. Granites of the S-type are almost invariably reduced (Blevin, 2004). The $S n \pm W$ deposits are typically related to ilmenite-series granite and $\mathrm{Cu}, \mathrm{Mo}$ and $\mathrm{Au}$ deposits are related to magnetite-bearing (oxidised) granite (Ishihara, 1981). The hydrothermal redistribution process depends on the oxidation state of the igneous system (Lehmann, 1994). Hydrothermal Sn ore-forming environments have a low oxidation state, opposite to Mo, which is mobilised in much more oxidised environments, incidentally like Au. Tungsten appears to be less redox-sensitive and is redistributed in both reducing and oxidising environments.

The mean composition of the major elements of the Almoughlagh batholith and the mean composition of the plutons associated with skarn deposits are compared in Table 4 . To evaluate the ore potential of the Almoghlagh batholith, employing discriminative diagrams and also comparing the Almugholagh composition with the known compositions of skarn-forming batholiths, is a suitable approach. The composition of the present pluton, plotted in the alumina saturation diagram (Fig. 6) indicates that the composition of the Baba Ali 
Table 4. Major element compositions of plutons associated with $\mathrm{Fe}, \mathrm{Cu}, \mathrm{Zn}, \mathrm{W}, \mathrm{Mo}$ and Sn skarns (Meinert, 1995) and different groups of the Almoghlagh batholith.

\begin{tabular}{lrrrrrrrrrr}
\hline skarn type & Fe & \multicolumn{1}{c}{$\mathbf{A u}$} & $\mathbf{C u}$ & $\mathbf{Z n}$ & $\mathbf{W}$ & $\mathbf{M o}$ & $\mathbf{S n}$ & $\begin{array}{c}\text { Baba Ali } \\
\text { diorites }\end{array}$ & $\begin{array}{c}\text { quartz- } \\
\text { syenite } \\
\text { group }\end{array}$ & $\begin{array}{c}\text { syenogran- } \\
\text { ite group }\end{array}$ \\
& mean & mean & mean & mean & mean & mean & mean & mean & mean & mean \\
\hline $\mathrm{SiO}_{2}$ & 59.3 & 61.4 & 64.9 & 68.7 & 70.7 & 73.7 & 73.7 & 52.60 & 71.10 & 68.90 \\
$\mathrm{Al}_{2} \mathrm{O}_{3}$ & 16.8 & 16.2 & 16.0 & 14.3 & 14.2 & 13.4 & 13.6 & 17.05 & 12.91 & 14.38 \\
$\mathrm{TiO}_{2}$ & 0.8 & 0.6 & 0.5 & 0.4 & 0.3 & 0.2 & 0.2 & 4.36 & 0.48 & 0.42 \\
$\mathrm{Fe}_{2} \mathrm{O}_{3}$ & 2.8 & 2.6 & 2.5 & 1.8 & 1.4 & 0.9 & 0.8 & 4.52 & 1.34 & 2.55 \\
$\mathrm{FeO}$ & 4.5 & 3.7 & 2.4 & 1.3 & 1.5 & 1.1 & 1.3 & 5.35 & 0.24 & 1.39 \\
$\mathrm{MnO}_{\mathrm{CaO}}$ & 0.1 & 0.1 & 0.1 & 0.1 & 0.1 & 0.0 & 0.1 & 7.53 & 0.47 & 0.92 \\
$\mathrm{MgO}$ & 7.2 & 5.8 & 3.8 & 3.2 & 2.2 & 1.5 & 1.1 & 4.51 & 1.67 & 3.07 \\
$\mathrm{~K}_{2} \mathrm{O}$ & 3.0 & 3.2 & 1.8 & 1.0 & 0.2 & 0.5 & 0.3 & 0.70 & 3.02 & 5.00 \\
$\mathrm{Na}_{2} \mathrm{O}$ & 2.1 & 2.5 & 3.6 & 4.8 & 4.5 & 4.7 & 4.7 & 1.23 & 6.39 & 4.38 \\
$\mathrm{P}_{2} \mathrm{O}_{5}$ & 4.0 & 3.1 & 4.0 & 3.0 & 3.5 & 3.2 & 3.2 & 0.10 & 0.03 & 0.03 \\
\hline
\end{tabular}

diorite is well consistent with the composition of Fe-bearing plutons, whereas the syenogranite composition is similar to those that generate $\mathrm{Mo}, \mathrm{Zn}, \mathrm{Cu}$ skarn deposits. With respect to the total alkalines versus $\mathrm{SiO}_{2}$, most plutons associated with skarn deposits plot in the sub-alkaline field (Fig. 7) (Meinert, 1995).

The Almoughlagh batholith also plots in the field of sub-alkaline plutons, and particularly in the field of calc-alkaline plutons (Figs 7, 8). These plots show that the geochemical composition of the Almoughlagh granitoids is consistent with the composition of the plutons associated with $\mathrm{Fe}, \mathrm{Cu}$ and Mo skarns. The variation in $\mathrm{K}_{2} \mathrm{O}$ and $\mathrm{MgO}$ vs. $\mathrm{SiO}_{2}$ (Fig. 10) indicates that the $\mathrm{Ab}$ composition varies along a spectrum representing two end-members ranging from Sn-skarn plutons to Fe-skarn plutons. Of interest is their close relationship with the differentiation trend of the batholith. There is a good correspondence between the Almoghlagh granitoids and the compositions of those recognised with the $\mathrm{Fe}, \mathrm{Cu}$, and $\mathrm{Zn}$ skarns. Illustrating the iron-oxidation state vs. $\mathrm{SiO}_{2}$ (Fig. 14) indicates a clear correspondence between the Almoughlagh granitoids (quartz syenite and syenogranite) and those bearing $\mathrm{Cu}$ - and Zn-skarn deposits, whereas the relationship between the Baba Ali diorite and the composition of the plutons that are accompanied by Fe skarn deposits is relatively distinct (Meinert, 1995). Interestingly, these phases of different mineralisation in skarn rocks are related with both the $\mathrm{SiO}_{2}$ content and the portioning of total iron, calcium and sodium with respect to the potassium content of the plutons. It is important in this context to point out that the plutons that are accompanied by $\mathrm{Fe}-\mathrm{Cu}$ skarns show a high degree of portioning of the above constituents (Fig. 15). The diagram is applicable to both the oceanic island-arc type and

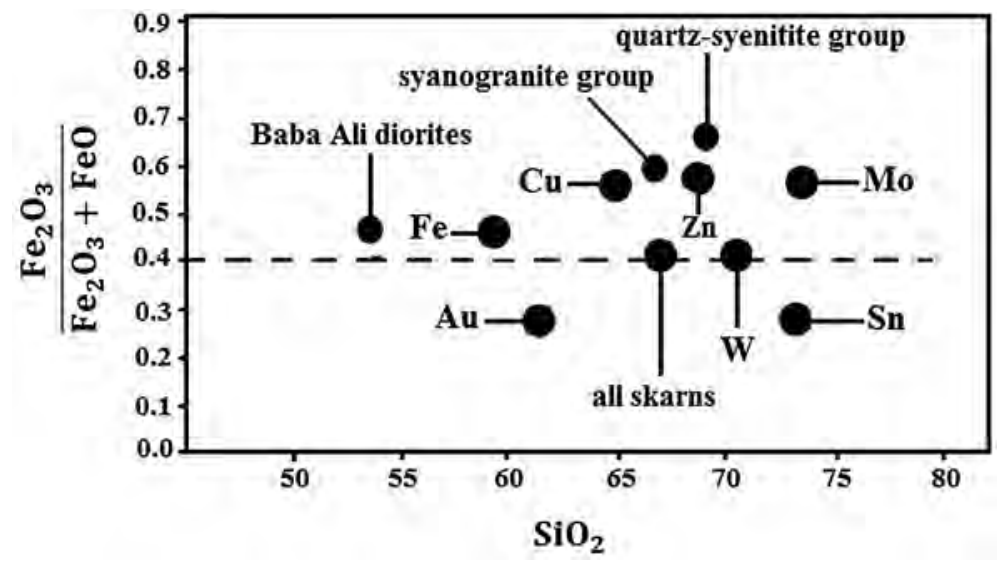

Fig. 14. Iron oxidation state vs. $\mathrm{SiO}_{2}$ content of the Almoghlagh batholith (from Meinert, 1995). 


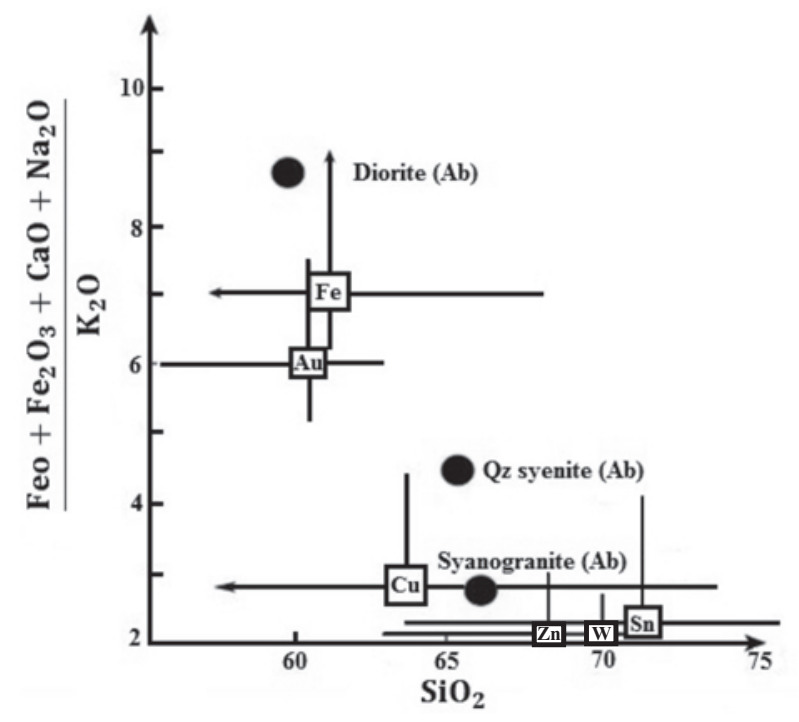

Fig. 15. Average composition of the Almoughlagh batholith $(\mathrm{Ab})$, compared to plutons accompanied by $\mathrm{Fe}$, $\mathrm{Cu}, \mathrm{Au}$ and Sn skarn deposits (after Meinert, 1992).

the volcanic-arc type skarn deposits (Meinert, 1993). It is also interesting that the Almoughlagh batholith shows an intensive portioning of the total $\mathrm{Fe}, \mathrm{CaO}$ and $\mathrm{Na}_{2} \mathrm{O}$ with respect to $\mathrm{K}_{2} \mathrm{O}$. The composition therefore points towards less crustal influence and to intensive differentiation for the Almoughlagh batholith. Geochemical and petrographic data show that this batholith can be classified as an I-type granite and as a member of the magnetite series (Zamanian, 2003). Such a batholith is considered as a possible source which could produce mineralised fluids responsible for the formation of skarn deposits (Einaudi \& Burt, 1982).

Thus, based on geochemical criteria, the composition of the Baba Ali diorite has been largely responsible for the Fe mineralisation. The $\mathrm{Ab}$ granitoids have an intermediate composition, mostly metaluminous, and their subsolvous character must also have allowed solubility of volatiles (Meinert, 1993).

Considering these characters and the mineralisations of $\mathrm{Fe}$ and $\mathrm{Cu}(\mathrm{Cu}$ mineralisation as chalcopyrite occurs with magnetite in the iron-skarn deposits of the area), further investigation and exploration are needed to find out whether Mo- and Zn-skarn mineralisations are present (due to Almoughlagh hydrothermal activities) or not. Despite the mantle source for the $\mathrm{Ab}$, the similarity of the syenogranite and the quartz-syenite compositions with the plu- tons associated with Mo- and Sn-skarn deposits could be interpreted as the result of contamination (by mixing) of mantle melts with crustal material during the uprising of the magma.

\section{Conclusions}

The Almoughlagh granitoids have an intermediate composition, mostly metaluminous, and their subsolvous character must have enabled volatiles to be dissolved. The abundance of perthitic and granophyric textures in the different rock types of the Almoughlagh batholith, indicate escape and emanation of volatiles from the batholith, which influenced both the encompassed Baba Ali diorite and the surrounding Songhor Series. The composition of the $\mathrm{Ab}$ shows less crustal influence and intensive differentiation, so that it can be classified as an I-type granite and as a member of the magnetite series. Such a batholith is a possible source of mineralised fluids responsible for the formation of skarn deposits.

Discriminative geochemical diagrams indicate that the Baba Ali diorite is responsible for iron mineralisation in the Baba Ali and Chenar mines, whereas the syenogranite must be held responsible for the $\mathrm{Cu}$ mineralisation which occurred as chalcopyrite in the Baba Ali skarn deposit. Based on their geochemistry, the syenogranite and the quartz syenite resemble compositionally plutons associated with Moand Zn-skarns. This will help future exploration activities searching for probable Mo and Zn skarn mineralisations.

\section{Acknowledgments}

The help extended by the Director, scientists and staff of the Geological Survey of Iran in providing all the necessary maps, documents and publications needed for this work is gratefully acknowledged. We thank the Director of RSIC, IIT, Mumbai for access to analytical facilities and the Head of the Department of Geology, University of Mysore, for the E.M.P. work. The help extended by the Department of Metallurgy, College of Engineering, Pune, for ore polishing is appreciated. The Iranian Ministry of Science and Technology sponsored this work. 


\section{References}

Agrawal, S., 1999, Geochemical discrimination diagram: A simple way of replacing eye-fitted field boundaries with probability based classifier surfaces. Journal Geological Society of India 45, 335-346.

Amiri, M., 1995. Petrography of the Almoughlagh. Unpublished Ph.D. thesis, University of Tarbit-e-Moalem (Tehran), 231 pp. [in Persian].

Baker, T., Pollard, P.J., Mustard, R., Mark, G. \& Graham, J.L., 2005. A comparison of granite-related tin, tungsten and gold-bismuth deposits: implications for exploration. Society of Economic Geologists Newsletter 61, 5-17.

Barud, J., 1975. Geological map of the Kermanshahan qudrangle (1:250000). Geological Survey of Iran (Tehran).

Berberian, M. \& King, G.C.P., 1981. Towards a paleogeography and tectonic evolution of Iran. Canadian Journal of Earth Sciences 18, 210-265.

Blevin, P.L., 2004. Redox and compositional parameters for interpreting the granitoid metallogeny of eastern Australia: implications for gold-rich ore systems. Resource Geology 54, 241-252.

Blevin, P.L. \& Chappell, B.W., 1995. Chemistry, origin and evolution of mineralised granitoids in the Lachlan fold belt, Australia; the metallogeny of I- and S-type granitoids. Economic Geology 90, 1604-1619.

Bose, M., 1991. Igneous petrology. World Press, Calcutta, $568 \mathrm{pp}$.

Chappell, B.W. \& White, A.J.R., 1984. I- and S-type granites in the Lachlan fold belt, southern Australia. [In:] Xu Kequin \& Tu Guangchi (Eds): Geology of granites and their metallogenic relations. Science Press, Beijing, 87-101.

Darvishzadeh, A., 1992. Geology of Iran. Nashre Danesh (Tehran), 901 pp. [in Persian].

Einaudi, M.T. \& Burt, D.M., 1982. Introduction - terminology, classification, and composition of skarn deposits. Economic Geology 77, 745-754.

Irvine, T.N. \& Baragar, W.R.A., 1971. A guide to the chemical classification of the common volcanic rocks. Canadian Journal of Earth Sciences 8, 523-548.

Ishihara, S., 1981. The Granitoid Series and mineralization. Economic Geology 75, 458-484.

Lehmann, B., 1994, Petrochemical factors governing the metallogeny of the Bolivian tin belt. [In:] K.J. Reutter, E. Scheuber \& P.J. Wigger (Eds): Tectonics of the southern Central Andes. Structure and evolution of an active continental margin. Springer, Berlin, 317-326.

Liou, J.G., 1973. Synthesis and stability relation of epidote, $\mathrm{Ca}_{2} \mathrm{Al}_{2} \mathrm{FeSi}_{3} \mathrm{O}_{24}(\mathrm{OH})$. Journal of Petrology 14, 381-413.
Meinert, L.D., 1984. Mineralogy and petrology of iron skarn in western British Columbia, Canada. Economic Geology 79, 869-882.

Meinert, L.D., 1992. Skarns and skarn deposits. Geosciences of Canada 19, 145-162.

Meinert, L.D., 1993. Igneous petrogenesis and skarn deposits. [In:] R.V. Kirkham, W.D. Sinclair, R.I. Thorpe \& J.M. Duke (Eds): Mineral deposit modeling. Geological Association of Canada Special Paper 40, 569-583.

Meinert, L.D., 1995. Compositional variation of igneous rocks associated with skarn deposits - Chemical evidence for a genetic connection between petrogenesis and mineralization. [In:] J.F.H. Thompson (Ed.): Magmas, fluids, and ore deposits. Mineralogical Association of Canada. Short Course Series 23, 401-418.

Miyashiro, A., 1974. Volcanic rock series in island arcs and active continental margins. American Journal of Sciences 274, 321-355.

Nabavi, M.H., 1971. Review of the geology of Iran. Unpublished report Geological Survey of Iran (Tehran).

Perkins, D., 2002. Mineralogy. $2^{\text {nd }}$ ed. Prentice Hall of India, Delhi, 483 pp.

Ramdohr, P., 1980. The ore minerals and their intergrowth. $2^{\text {nd }}$ ed. Pergamon Press, London, 1205 pp.

Ratnakar, J. \& Vijaya Kumar, K., 1995. Petrogenesis of quartz syenite occurring within nephelinesyenite of the Elchuru alkaline complex, Prakasam Province Andhara Pradesh. Journal Geological Society of India 46, 611-618.

Shimazaki, H., 1980. Characteristics of skarn deposits and related acid magmatism in Japan. Economic Geology 75, 173-183.

Taylor, S.R. \& McLennan, S.M., 1985. The continental crust: its composition and evolution. Blackwell, Oxford, 312 pp.

Valizadeh, M.V. \& Cantagral, J.M., 1975. Premières données radiométriques (K-Ar et $\mathrm{Rb}-\mathrm{Sr}$ ) sur les micas du complex magmatique du Mont Alvand. Comptes Rendue de l'Académie des Sciences d'Outre-Mer 281, 1083-1086.

Zamanian, H., 2003. Iron mineralization related to the Almoughlagh and south Ghorveh batholiths with specific reference to the Baba Ali and Gelali deposits. Ph.D., thesis University of Pune, 220 pp.

Zamanian, H., 2007. Geology of the Gelali iron mineralization related to the south Ghorveh batholith, western Iran. Journal of Earth Science 1, 47-65.

Manuscript received: 15 November 2012 Revision accepted: 15 July 2013 